\title{
The spatial pattern analysis of settlements area in Batusangkar City Tanah Datar Regency
}

\author{
Rery Novio *, Sri Mariya ", Bayu Wijayanto * \\ * Department of Geography Faculty of Social Sciences Universitas Negeri Padang, \\ Indonesia
}

\begin{tabular}{l}
\hline \hline ARTICLES INFO \\
\hline Profil Articles: \\
Sent: 19-10-2019 \\
Approved: 6-12-2019 \\
Published: 30-1-2020
\end{tabular}

Key words:

spatial pattern;

populations; settlements

\section{Correspondent Author:}

Rery Novio

Department of Geography

Universitas Negeri Padang

Jl. Prof. Dr. Hamka, Air Tawar Barat, Padang Utara, Kota Padang, Indonesia

E-mail: rerynovio@fis.unp.ac.id
The spatial distribution of populations and settlements is in line with connectivity and accessibility within a city area. Delineation of Batusangkar City exists in 3 sub-districts and 6 Nagari, causing settlement concentration in certain areas will form a certain distribution pattern and different settlement, the occurrence of diversity patterns distribution as a form of uneven population distribution. So that information is needed regarding changes in land use and patterns of settlement distribution in relation to land use in urban planning. This study aims to discover the changes in area and distribution patterns of settlements. This research method is quantitative descriptive using secondary data and then analyzed using the nearest neighbor analysis. The results of the study showed the change in the distribution of settlements to areas close to public facilities such as offices, schools, and universities. Batusangkar City area has a Pureisolated type pattern, while based on the Alvin L. Bertrand category it has a Line Village Community pattern, then based on the calculation of the nearest neighbor analysis it is categorized as Clustered.

This is an open access article under the CC-BY-SA license

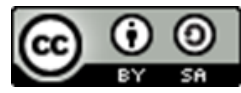

INTRODUCTION
Are there any spatial patterns or geographic arrangements in city locations, industrial factories, trees in the forest, earthquake centers, disease outbreaks, or bird species nests? Geographers and other scientists look for geographic or spatial patterns in various phenomena, hoping that this will lead to a better understanding of the processes that produce such patterns. In searching for a pattern, or spatial relationship, by mapping the location where certain objects are located. Humans as social being mean humans do not live alone but live together and form groups, as well as the houses where they live, will be built together so that groups or scattered in an area, equipped with the infrastructure and facilities needed by its inhabitants, hereinafter referred to as a settlement.

Settlements are categorized into two parts, namely urban settlements, and rural settlements. Although the characteristics of the two settlements have similarities it will be different when viewed based on variations in geographical conditions of an area. In 
Jurnal Pendidikan Geografi:

Kajian, Teori, dan Praktik dalam Bidang Pendidikan dan Ilmu Geografi

Volume 25, Nomor 1, Jan 2020, Hal 80-87

line with this, Koestoer (Mulyana, 2013) states that settlements are closely related to the concept of the environment with spatial planning so that settlements are areas of land that are used as residential or residential environments and where activities support life and are part of the environment live outside protected areas in the form of urban and rural areas.

Basically, spatial analysis is a location analysis that focuses on three geographical elements, namely distance, link and movement. People's dissatisfaction in discussing settlement patterns descriptively gave an idea to discuss quantitatively. Settlement patterns are said to be uniform, random or clustered and so on can be given quantitative measures. In this way the comparison between settlement patterns can be done better, not only in terms of time but also in terms of space. This approach is called the Nearest Neighbor Analysis (NNA). This kind of analysis requires data about the distance between one settlement and the closest settlement, which is the closest neighbor. In this connection, each settlement is considered a point in space. Nevertheless this closest neighbor analysis can also be used to assess the pattern of the spread of other phenomena such as the pattern of the spread of landslides, the distribution patterns of Puskesmas, the distribution patterns of water sources and so on. This NNA is suitable for areas where there is no natural obstacle between one settlement and another that cannot be overcome, for example the distance between two settlements that are relatively close but separated by a gap. Therefore, for areas that constitute a plain where the relationship between one settlement and other settlements has no significant natural barriers, then this analysis of the nearest neighbors will show practical value, for example for designing the location of social service centers such as hospitals, schools, post offices, recreation centers and so on.

Land use structure is a reflection of the economy structure and people's preferences. This economic structure and community preferences are dynamic in line with population growth and development dynamics, so that the land use structure is dynamic. The dynamics of land use structure can develop in the direction of increasing community welfare and vice versa, due to accumulation of social costs, and inter temporal costs. Agricultural conversion that occurs also is a consequence such as the expansion of cities that require land for urban economic growth. High urbanization in Indonesia is triggered by differences in economic growth that is too large between urban and rural areas, resulting in an increase in urban demand for land for other infrastructure and facilities that require land availability (Rustiadi, 2007).

Although cities played an important role throughout human history, it was not until the industrial revolution that a network of large cities began to emerge in the most economically advanced part of the world. Since 1950, the world's urban population has more than doubled, reaching nearly 3.8 billion in 2014, around $54 \%$ of the global population (Rodrigue, 2017). This transition is expected to continue into the second half of the 21 st century, a trend that reflected in the size of the city that is getting bigger and increasing the proportion of urban population. Cities also dominate national economic output because they are responsible for the majority of production, distribution, and consumption.

Current global trends show growth of around 50 million urban areas each year, approximately one million per week. More than $90 \%$ of that growth occurred in developing countries which put strong pressure on urban infrastructure, especially transportation, to overcome it. In 2050, 6.4 billion people, around two-thirds of humanity, will most likely be urban dwellers. What can be considered urban covers a whole set of urban spatial structures, from small cities to large urban agglomeration 
(Rodrigue, 2017). This also raises the question of optimal city size because technical limitations (roads, utilities) do not impede much in building a very large city. Many of the largest cities in the world can be labeled as dysfunctional mainly because when the size of the city increases the increased complexity is not effectively overcome by managerial expertise.

Cities in Indonesia must find the right way to overcome various urban problems and grow into cities that are livable, self-conscious, productive and sustainable. Batusangkar, geographically, is a city where significant population concentrations occur in 6 villages, namely Lima Kaum, Baringin, Parambahan, Pagaruyung, Saruaso and Cubadak. Lima Kaum is the most populous region which reaches 696 inhabitants per $\mathrm{km} 2$. The pattern of population development in the Batusangkar is linear but it is expected that external factors will affect regional economic development (Tanah Datar). Then based on the Spatial Plan of Tanah Datar Regency, the Batusangkar Area will be encouraged and developed as a Local Activity Center that serves several districts scale activities. It is also intended as a residential area, therefore it is important to see how the spatial pattern of settlement development in the Batusangkar City.

\section{METHOD}

Based on the title and the formulation of the problem, the type of the research is quantitative analysis. Descriptive research methods are used if the research aims to describe the data or explain the events and studies that exist in the present (Sugiyono, 2007: 65). Research location: Batusangkar City area which consists of 3 Sub-districts namely Lima Kaum, Rambatan, and Tanjung Emas which consists of 6 villages including: Lima Kaum, Baringin, Parambahan, Pagaruyung, Saruaso and Cubadak.

The data used in this research is secondary data. Secondary data is data obtained from documents and records that have been available in a particular agency. In this study, data were obtained from the Regional Development Planning Bureau / Badan Perencanaan dan Pembangunan Daerah (BAPPEDA) in the form of administrative, geological, land and land use areas, then from the Central Statistics Bureau / Badan Pusat Statistik (BPS) in the form of area, population, population density, natural products in the form of agriculture or plantations, and from Landsat Imagery to see changes in settlement development. In this study the determination of points is done by making a Grid line and then determining the settlement center point in every $1 \mathrm{Km}^{2}$ by seeing which areas are the center of settlements so that area is the point. In this study, the distance between one point and another can be measured by drawing a straight line from one point to another, which is the closest point.

The analysis method used in this study is a quantitative approach using nearest neighbor analysis, with the stages to be carried out in this study, namely Collect the data needed for research, determine the boundaries to be investigated, change the pattern of object distribution into the pattern of point distribution, provide sequence numbers for each point to facilitate analysis, and give the closest distance, which is the distance in a straight line between one point and another point that is the nearest neighbor and record the size of this distance.

Then next to find out the pattern of settlement using data analysis using the nearest neighbor analysis method with the following formula:

$$
\begin{array}{ll}
\bar{d}_{e}=\frac{1}{2 \sqrt{n / A}} & \bar{d}_{o}=\sum_{i=1}^{m} d_{i j} / n=\frac{23.976}{111}=0.216 \\
\bar{d}_{e}=\frac{1}{2 \sqrt{111 / 107.16}}=\frac{1}{2.036}=0.491
\end{array}
$$


Jurnal Pendidikan Geografi:

Kajian, Teori, dan Praktik dalam Bidang Pendidikan dan Ilmu Geografi

Volume 25, Nomor 1, Jan 2020, Hal 80-87

So that

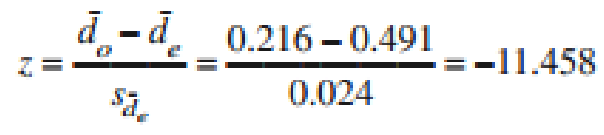

In this study the determination of points is done by making a Grid line and then determining the settlement center point in every $1 \mathrm{Km} 2$ by seeing which areas are the center of settlements so that area is the point. In this study, the distance between one point and another can be measured by drawing a straight line from one point to another, which is the closest point.

\section{RESULT AND DISCUSSION}

Land use change is a change in land use or activity that is different from previous activities. Land use is divided into two main groups namely agricultural land use and non -agricultural land use. Changes in land use can also be interpreted by increasing a land use from one side of use to another followed by a decrease in other types of land use from one time to the next, or changes in the function of a land at different periods (Wahyunto, 2014).

The increasing number of population and development activities demands the availability of land especially residential land and facilities also increase rapidly, while the availability of land is limited. This imbalance allows settlements concentration in certain regions, or regions which then will form a pattern of distribution of certain settlements and vary, the occurrence of diversity patterns of settlement distribution as an expression of uneven population distribution. So that information is needed regarding changes in land use and patterns of settlement distribution in relation to land use in urban planning. (Dian Ayu Saraswati, 2016).

\section{Settlement}

Settlement is a basic need that is very important in human life. In five basic needs for human life for food, clothing, settlement, education and health, it appears that settlements occupy a central position, thus increasing settlements will also improve the quality of life. Settlement is described as a place to live or an area, where the population groups and live together. They build houses, roads and so on for their sake. In this sense, the meaning of settlement is more towards physical form, as human and population activities in fulfilling part of their lives, especially the needs of residence (Bintarto, 1987).

Different patterns of settlement distribution are also influenced by the topography of an area. The topography referred is the altitude and slope. The height of the place and the slope affect humans in choosing and establishing settlements. Humans tend to live in a flat place with a low altitude of $\pm 2-100 \mathrm{~m}$ above sea level and with a slope of about 0 $15 \%$ (USDA in BAPPEDA, 2011), because in that area the carrying capacity of the land is good for building a settlement because it has the power of the land to support or hold the load of the foundation without collapse due to sliding, so that in the topographical conditions the distribution pattern of the settlement will lead to random and even uniform patterns (Dian Ayu Saraswati, 2016). Batusangkar city area is located at an altitude of 200-1000 meters above sea level with a slope height mostly above $15 \%$. 
Jurnal Pendidikan Geografi:

Kajian, Teori, dan Praktik dalam Bidang Pendidikan dan Ilmu Geografi

Volume 25, Nomor 1, Jan 2020, Hal 80-87

\section{Settlement Pattern}

Spatial analysis is a location analysis that focuses on three geographical elements, namely distance, interaction and movement (Bintarto, 1987). People's dissatisfaction discusses settlement patterns descriptively giving an idea of discussing them quantitatively.

Bintarto and Surastopo Hadisumarno in Anggit (2017: 32) said that the pattern of settlements and settlement arrangements has a very close relationship. The settlement arrangement discusses matters where there are settlements and where they are not located in an area, or with other statements, settlement arrangement talk about settlement

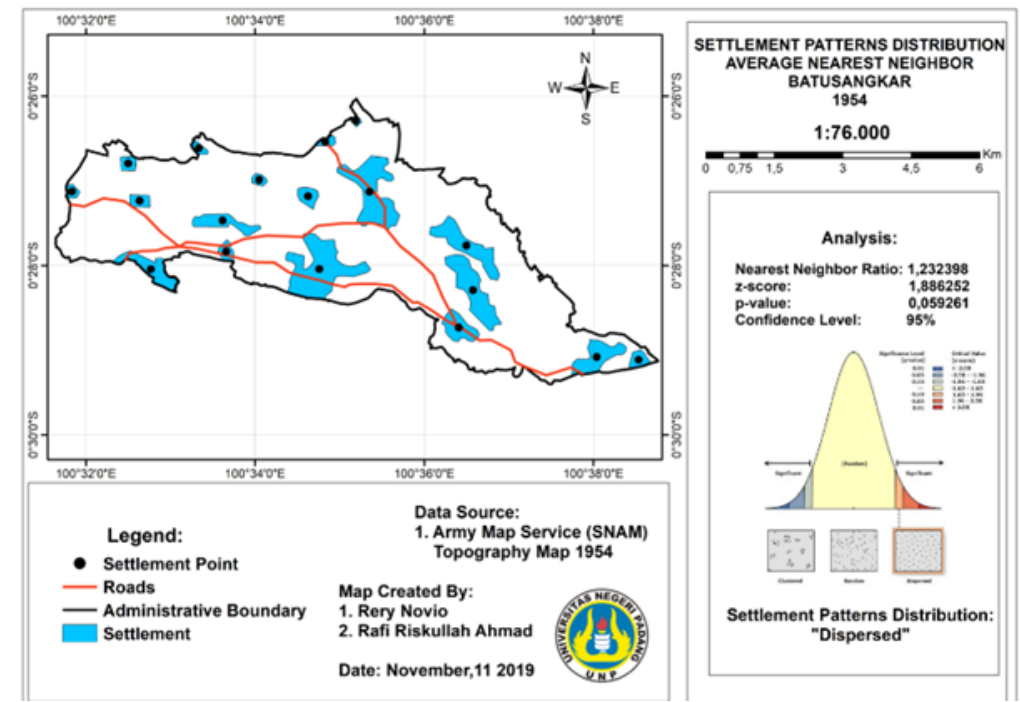

Figure 1. settlement pattern in 1954

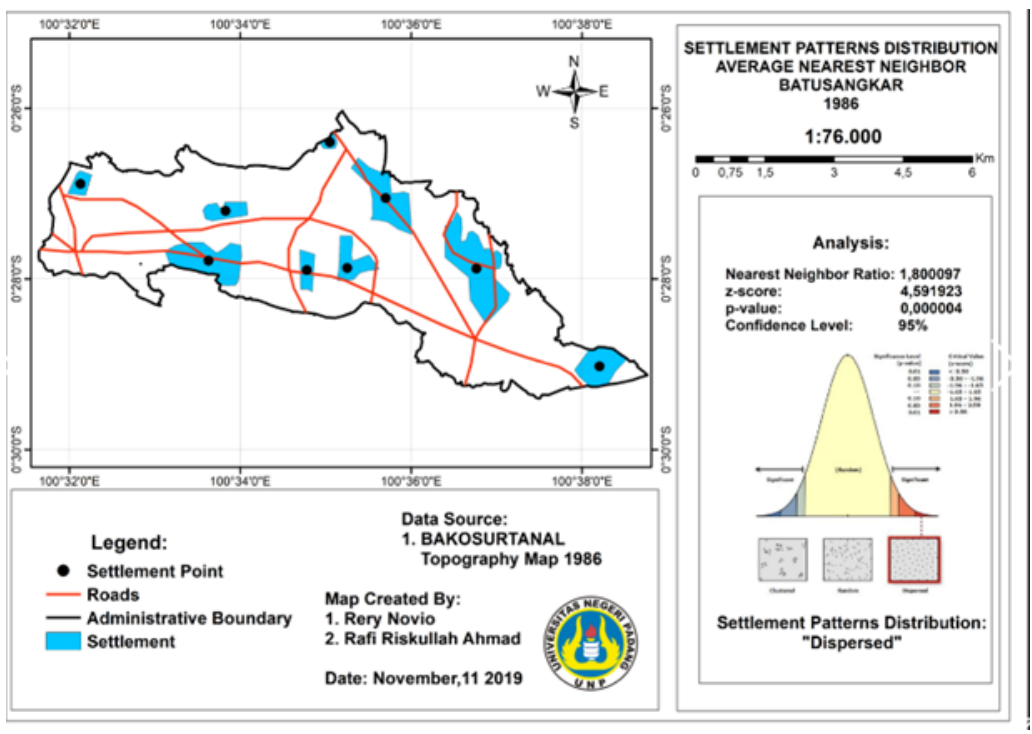

Figure 2. settlement pattern in 1986 
Jurnal Pendidikan Geografi:

Kajian, Teori, dan Praktik dalam Bidang Pendidikan dan Ilmu Geografi

Volume 25, Nomor 1, Jan 2020, Hal 80-87

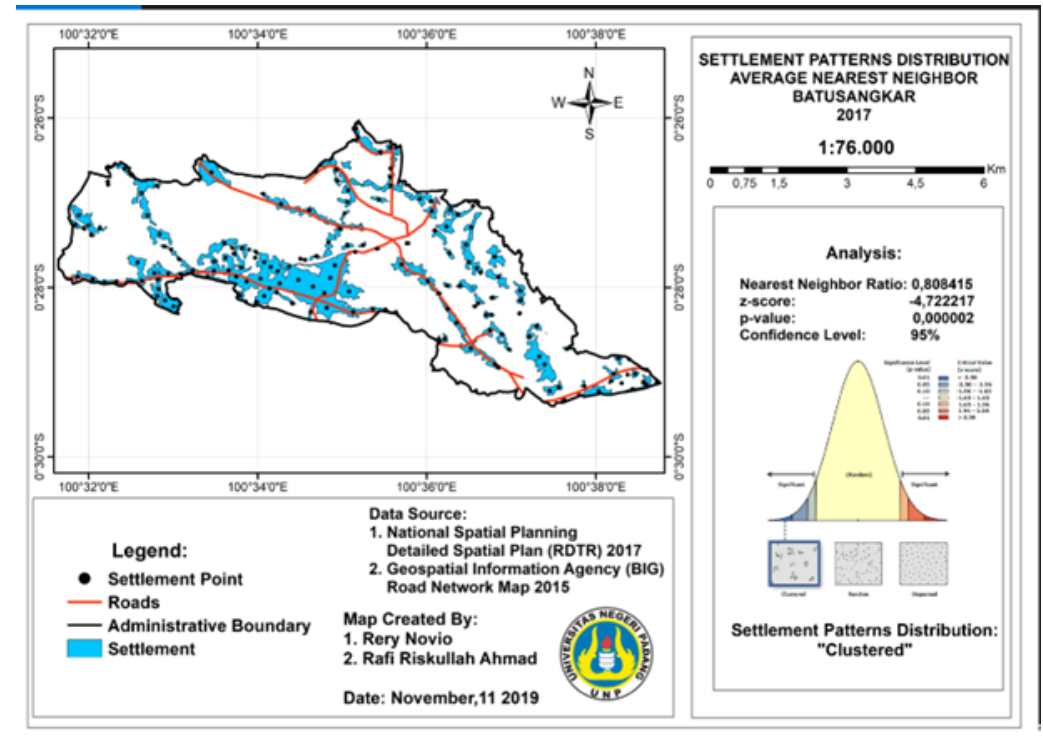

Figure 3. settlement pattern in 2017

locations. Settlement patterns discuss the nature of settlement arrangement. This pattern of settlement is very different from the pattern of type or patterned way of moving people from one area to another, which includes the process of resident placement or resettlement from the original settlement to the new settlement. Distinguishes informal from formal neighborhoods in developing countries by analyzing shape (form), terrain geomorphology, texture, road networks and dominant settlement materials (vegetation, soil, asphalt) to produce a multivariate, spatially explicit evaluation of settlement structure. The principal datasets require only high resolution imagery and elevation data which are both widely available (Karen K. Owen, 2013).

While the pattern of distribution of village settlements, according to Paul $\mathrm{H}$. Landis (in Bintarto, 1983: 43), emphasizes more on the agrarian aspect, namely agriculture as a field of livelihood for most rural residents. The classifications include: (1) The farm village type, is the type of village where the population lives together in a place with agricultural land around it, (2) The nebulous farm type, is a type of village where most of the population lives together in a place with agricultural land around it and a small portion of the population is spread out of the main settlement because the main settlement is already dense, (3) The arranged isolated farm type, is the type of village whose inhabitants live along the main road, and (4) Pure isolated type, is a type of village where people live scattered, separated from their respective agricultural land and concentrated in one trade center.

In line with Paul H. Landis, according to Alvin L. Bertrand (in Bintarto, 1983: 46), the pattern of village settlements distribution has a combination of similarities with the theories of Bintarto and Landis, but is also related to the location of the people's livelihoods, which are as follows: (1) Nucleated Agricultural Village Community, namely village settlements clustered, the distance of agricultural land far from residential areas, (2) Line Village Community is a settlement in the form of a longitudinal row on either side of the road or river. Residents arrange their houses to follow the river flow or the road which is the livelihood traffic lane and form a row of housing, (3) Open Country Village, which is where villagers choose or build dwellings scattered in an agricultural 
Jurnal Pendidikan Geografi:

Kajian, Teori, dan Praktik dalam Bidang Pendidikan dan Ilmu Geografi

Volume 25, Nomor 1, Jan 2020, Hal 80-87

area, so that it is possible for trade relations, because of differences in production and needs. This pattern is also called the trade center community.

The most common criteria for determining the spatial boundaries of settlements can be grouped into three broad categories: 1) homogeneity, based on spatial units that can be grouped in the minimum statistical variation statistical parameters of simple indicators (EUROSTAT, 2012); 2) functional, based on spatial units grouped among those who have an intense exchange of people, goods or communication flows, morphologically, according to which one can define a spatial continuum through land cover patterns (Weber, 2001). In all of these criteria, the typical difficulties encountered stem from the spatial heterogeneity of the settlement patterns and the non -uniform availability of data (Rodrigues, 2015). The development of settlements from several time periods always occurs significantly. In 1954 and 1986 the pattern of settlements in Batusangkar was in calculation of the nearest neighbor analysis the dispersed category. Then in 2017, the pattern of settlements of the Batusangkar was in the clustered category . Remote sensing of human settlement patterns has experienced an upward trend in volume especially during the current 21st "urban century (T.W. Crawford, 2018)

Based on the Paul Landis Category map of the distribution of settlements, the Batusangkar City Area has a Pureisolated type pattern, which is a type of village whose inhabitants live scattered, separated from their respective agricultural lands and concentrated in one trade center. While based on the Alvin L. Bertrand category, the Line Village Community pattern is a settlement in the form of a longitudinal row on either side of the road or river. Residents arrange their houses to follow the river flow or the road which is the livelihood traffic lane and form a row of housing. As socioeconomic development progresses (division of labor in society, industrialization and urbanization), changes on the spatial structure and function take place in the rural settlements (Yanbo Qu, Jiang Guanghui, Qingley Zhaou, 2017).

\section{Conclusion}

Humans as social beings then humans do not live alone but live together and form groups, as well as the houses where they live will be built together so that groups or scattered in an area, equipped with the infrastructure and facilities needed by its inhabitants, hereinafter referred to as settlement. Different patterns of settlement distribution are also influenced by the topography of an area. Batusangkar City area has a Pureisolated type pattern, while based on the Alvin L. Bertrand category it has a Line Village Community pattern, then based on the calculation of the nearest neighbor analysis it is categorized as Clustered.

\section{Acknowledgments}

This research was supported/partially supported by Mrs Ahyuni gift a idea. We thank our colleagues from Universitas Negeri Padang who provided insight and expertise that greatly assisted the research, although they may not agree with all of the interpretations/conclusions of this paper.

\section{References}

Bintarto, H. S. (1987). Metode Analisa Geografi. Jakarta: LP3ES.

Dian Ayu Saraswati, S. S. (2016). ANALISIS PERUBAHAN LUAS DAN POLA PERSEBARAN PERMUKIMAN. Jurnal Geodesi UNDIP , Volume 5, Nomor 1, Tahun 2016, (ISSN : 2337-845X) 155-163.

EUROSTAT. (2012). "Focus on territorial typologies", in Eurostat regional yearbook 2012. Luxembourg: Publications Office of the European Union, pp. 195-201.

Karen K. Owen, D. W. (2013). An approach to differentiate informal settlements using 
Jurnal Pendidikan Geografi:

Kajian, Teori, dan Praktik dalam Bidang Pendidikan dan Ilmu Geografi

Volume 25, Nomor 1, Jan 2020, Hal 80-87

spectral, texture, geomorphology and road accessibility metrics. Applied Geography, Volume 38, March 2013, Pages 107-118.

Mulyana, R. (2013). Merancang Pemukiman Sehat dan Berwawasan Lingkungan. Medan: UNIMED.

Rodrigue, J.-P. (2017). The Geography Of Transport System. Newyork: Routledge.

Rodrigues, M. (2015). A spatial typology for settlement pattern analysis in small islands. GeoFocus, no15, ISSN: 1578-5157 p. 3-26.

Rustiadi, E. (2007). Perencanaan dan pengembangan wilayah. Bogor: Institut Pertanian Bogor.

T.W. Crawford, M. R. (2018). settlement patterns. In R. Holloway, Reference Module in Earth Systems and Environmental Sciences (pp. 106-122). London: Elsevier.

Wahyunto, D. (2014). Analisis Perubahan Lahan Untuk Permukiman di Kecamatan Kaliwungu dengan Sistem Informasi Geogarafis. Semarang: Unnes.

Weber, C. (2001). Urban agglomeration delimitation using remote sensing data. In J. Donnay, \& M. \&. Barnsley, Remote sensing and urban analysis (pp. 145-160). London: Taylor and Francis.

Yanbo Qu, Jiang Guanghui, Qingley Zhaou, . (2017). Geographic identification, spatial differentiation, and formation mechanism of multifunction of rural settlements: A case study of 804 typical villages in Shandong Province, China. Journal of Cleaner Production, Volume 166 1202-1215. 